\title{
Erratum to: comparative genomics and evolution of the amylase-binding proteins of oral streptococci
}

\author{
Elaine M. Haase ${ }^{1 *}$, Yurong Kou ${ }^{1,4}$, Amarpreet Sabharwal ${ }^{1}$, Yu-Chieh Liao ${ }^{2}$, Tianying Lan ${ }^{3}$, Charlotte Lindqvist ${ }^{3}$ \\ and Frank A. Scannapieco ${ }^{1}$
}

\section{Erratum}

Upon publication of the original article [1] discrepancies were highlighted in the references of this manuscript. On page 11, the references in the following sentence should be amended "Homologs are now found in many oral streptococcal species of humans and animals whose saliva contains amylase activity [32, 33]." Citation 33 should read 34 and was incorrectly amended during the proofing process. In addition, an updated reference list has been included below as two references were accidentally omitted.

\section{Updated reference list}

1. Bentley RW, Leigh JA, Collins MD. Intrageneric structure of Streptococcus based on comparative analysis of small-subunit rRNA sequences. Int J Syst Bacteriol. 1991;41(4):487-94. doi:10.1099/00207713-41-4-487.

2. Kawamura Y, Hou XG, Sultana F, Miura H, Ezaki T. Determination of $16 \mathrm{~S}$ rRNA sequences of Streptococcus mitis and Streptococcus gordonii and phylogenetic relationships among members of the genus Streptococcus. Int J Syst Bacteriol. 1995;45(2):406-8. doi:10.1099/ 00207713-45-2-406.

3. Brown AE, Rogers JD, Haase EM, Zelasko PM, Scannapieco FA. Prevalence of the amylase-binding protein A gene $(a b p A)$ in oral streptococci. J Clin Microbiol. 1999;37(12):4081-5.

4. Douglas CW, Heath J, Hampton KK, Preston FE. Identity of viridans streptococci isolated from cases of infective endocarditis. J Med Microbiol. 1993;39(3):179-82. doi:10.1099/00222615-39-3-179.

5. Gwynn JP, Douglas CW. Comparison of amylasebinding proteins in oral streptococci. FEMS Microbiol Lett. 1994;124(3):373-9.

\footnotetext{
* Correspondence: haase@buffalo.edu

'Department of Oral Biology, School of Dental Medicine, University at

Buffalo, State University of New York, Buffalo, NY, USA

Full list of author information is available at the end of the article
}

6. Kilian M, Nyvad B. Ability to bind salivary alphaamylase discriminates certain viridans group streptococcal species. J Clin Microbiol. 1990;28(11):2576-7.

7. Karn RC, Shulkin JD, Merritt AD, Newell RC. Evidence for post-transcriptional modification of human salivary amylase (amyl) isozymes. Biochem Genet. 1973;10(4):341-50.

8. Boehlke C, Zierau O, Hannig C. Salivary amylase - The enzyme of unspecialized euryphagous animals. Arch Oral Biol. 2015;60(8):1162-76. doi:10.1016/ j.archoralbio.2015.05.008.

9. Aguirre A, Levine MJ, Cohen RE, Tabak LA. Immunochemical quantitation of alpha-amylase and secretory IgA in parotid saliva from people of various ages. Arch Oral Biol. 1987;32(4):297-301.

10. Scannapieco FA, Torres G, Levine MJ. Salivary alpha-amylase: role in dental plaque and caries formation. Crit Rev. Oral Biol Med. 1993;4(3-4):301-7.

11. Douglas CW. The binding of human salivary alpha-amylase by oral strains of streptococcal bacteria. Arch Oral Biol. 1983;28(7):567-73.

12. Rogers JD, Palmer RJ, Jr., Kolenbrander PE, Scannapieco FA. Role of Streptococcus gordonii amylasebinding protein $\mathrm{A}$ in adhesion to hydroxyapatite, starch metabolism, and biofilm formation. Infect Immun. 2001;69(11):7046-56.

13. Nikitkova AE, Haase EM, Vickerman MM, Gill SR, Scannapieco FA. Response of fatty acid synthesis genes to the binding of human salivary amylase by Streptococcus gordonii. Appl Environ Microbiol. 2012;78(6):1865-75. doi:10.1128/AEM.07071-11.

14. Rogers JD, Haase EM, Brown AE, Douglas CW, Gwynn JP, Scannapieco FA. Identification and analysis of a gene $(a b p A)$ encoding a major amylase-binding protein in Streptococcus gordonii. Microbiology. 1998;144 (Pt 5):1223-33. 
15. Li L, Tanzer JM, Scannapieco FA. Identification and analysis of the amylase-binding protein $\mathrm{B}(\mathrm{AbpB})$ and gene $(a b p B)$ from Streptococcus gordonii. FEMS Microbiol Lett. 2002;212(2):151-7.

16. Vorrasi J, Chaudhuri B, Haase EM, Scannapieco FA. Identification and characterization of amylasebinding protein C from Streptococcus mitis NS51. Mol Oral Microbiol. 2010;25(2):150-6. doi:10.1111/j.20411014.2009.00554.x.

17. Haase EM, Feng X, Pan J, Miecznikowski JC, Scannapieco FA. Dynamics of the Streptococcus gordonii transcriptome in response to media composition, salivary alpha-amylase and starch. Appl Environ Microbiol. 2015. doi:10.1128/AEM.01221-15.

18. Liang X, Chen $\mathrm{Y}, \mathrm{Wu} \mathrm{H}$. Sortase B assemble amylase-binding protein A to streptococcal cell surface. 89th Gen. Sess. of Internat. Assoc. Dent. Res.; San Diego, CA: IADR; 2011. p. 72.

19. Liang X, Liu B, Zhu F, Scannapieco FA, Haase EM, Matthews $\mathrm{S}$ et al. A distinct sortase SrtB anchors and processes a streptococcal adhesin AbpA with a novel structural property. Sci Rep. 2016;6:30,966. doi:10.1038/ srep30966.

20. Chaudhuri B, Paju S, Haase EM, Vickerman MM, Tanzer JM, Scannapieco FA. Amylase-binding protein B of Streptococcus gordonii is an extracellular dipeptidylpeptidase. Infect Immun. 2008;76(10):4530-7. doi:10.1128/IAI.00186-08.

21. Liao YC, Lin HH, Sabharwal A, Haase EM, Scannapieco FA. MyPro: A seamless pipeline for automated prokaryotic genome assembly and annotation. J Microbiol Methods. 2015;113:72-4. doi:10.1016/j.mimet.2015.04.006.

22. Sabharwal A, Liao YC, Lin HH, Haase EM, Scannapieco FA. Draft genome sequences of 18 oral streptococcus strains that encode amylase-binding proteins. Genome Announc. 2015;3(3):e00510-15 doi:10.1128/genomeA.00510-15.

23. Jensen A, Scholz CF, Kilian M. Re-evaluation of the taxonomy of the Mitis group of the genus Streptococcus based on whole genome phylogenetic analyses, and proposed reclassification of Streptococcus dentisani as Streptococcus oralis subsp. dentisani comb. nov., Streptococcus tigurinus as Streptococcus oralis subsp. tigurinus comb. nov., and Streptococcus oligofermentans as a later synonym of Streptococcus cristatus. Int J Syst Evol Microbiol. 2016;66(11):4803-20. doi:10.1099/ ijsem.0.001433.

24. Facklam R, Elliott JA. Identification, classification, and clinical relevance of catalase-negative, gram-positive cocci, excluding the streptococci and enterococci. Clin Microbiol Rev. 1995;8(4):479-95.

25. Collins M. The Genus Gemella. In: Dworkin M, Falkow S, Rosenberg E, Schleifer H, Stackebrandt E, editors. The Prokaryotes. New York: Springer; 2006. p. 511-8.

26. Gopal P, Ragunath C, Vyas V, Shanmugam M, Ramasubbu N. Probing the interaction of human salivary alpha-amylase and amylase binding protein A (AbpA) of Streptococcus gordonii. Mol Biol. 2013;2:111. doi:10.4172/2168-9547.100011.

27. Sievers F, Wilm A, Dineen D, Gibson TJ, Karplus K, $\mathrm{Li} \mathrm{W}$ et al. Fast, scalable generation of high-quality protein multiple sequence alignments using CLUSTAL Omega. Mol Syst Biol. 2011;7:539. doi:10.1038/msb.2011.75.

28. Takenouchi-Ohkubo N, Mortensen LM, Drasbek KR, Kilian M, Poulsen K. Horizontal transfer of the immunoglobulin A1 protease gene (iga) from Streptococcus to Gemella haemolysans. Microbiology. 2006;152(Pt 7):2171-80. doi:10.1099/mic.0.28801-0.

29. Sethi A, Mohanty B, Ramasubbu N, Gooley PR. Structure of amylase-binding protein A of Streptococcus gordonii: a potential receptor for human salivary alpha-amylase enzyme. Protein Sci. 2015;24(6):1013-8. doi:10.1002/pro.2671.

30. Douglas CW, Pease AA, Whiley RA. Amylasebinding as a discriminator among oral streptococci. FEMS Microbiol Lett. 1990;54(1-3):193-7.

31. Stamatakis A. RAxML version 8: a tool for phylogenetic analysis and post-analysis of large phylogenies. Bioinformatics. 2014;30(9):1312-3. doi:10.1093/bioinformatics/btu033.

32. Scannapieco FA, Haraszthy GG, Cho MI, Levine MJ. Characterization of an amylase-binding component of Streptococcus gordonii G9B. Infect Immun. 1992;60(11):4726-33.

33. Okahashi N, Nakata M, Terao Y, Isoda R, Sakurai A, Sumitomo T et al. Pili of oral Streptococcus sanguinis bind to salivary amylase and promote the biofilm formation. Microb Pathog. 2011;50(3-4):148-54. doi:10.1016/ j.micpath.2011.01.005.

34. Nikitkova AE, Haase EM, Scannapieco FA. Taking the starch out of oral biofilm formation: molecular basis and functional significance of salivary alpha-amylase binding to oral streptococci. Appl Environ Microbiol. 2013;79(2):416-23. doi:10.1128/AEM.02581-12.

35. Perrone M, Gfell LE, Fontana M, Gregory RL. Antigenic characterization of fimbria preparations from Streptococcus mutans isolates from caries-free and caries-susceptible subjects. Clin Diagn Lab Immunol. 1997;4(3):291-6.

36. Zulfiqar M, Yamaguchi T, Sato S, Oho T. Oral Fusobacterium nucleatum subsp. polymorphum binds to human salivary alpha-amylase. Mol Oral Microbiol. 2013;28(6):425-34. doi:10.1111/omi.12036.

37. Baik JE, Hong SW, Choi S, Jeon JH, Park OJ, Cho $\mathrm{K}$ et al. Alpha-amylase is a human salivary protein with affinity to lipopolysaccharide of Aggregatibacter 
actinomycetemcomitans. Mol Oral Microbiol. 2013;28(2):142-53. doi:10.1111/omi.12011.

38. Choi S, Baik JE, Jeon JH, Cho K, Seo DG, Kum $\mathrm{KY}$ et al. Identification of Porphyromonas gingivalis lipopolysaccharide-binding proteins in human saliva. Molecular immunology. 2011;48(15-16):2207-13. doi:10.1016/j.molimm.2011.06.434.

39. Ochiai A, Harada K, Hashimoto K, Shibata K, Ishiyama $\mathrm{Y}$, Mitsui $\mathrm{T}$ et al. alpha-Amylase is a potential growth inhibitor of Porphyromonas gingivalis, a periodontal pathogenic bacterium. J Periodontal Res. 2014;49(1):62-8. doi:10.1111/jre.12079.

40. Donati C, Hiller NL, Tettelin H, Muzzi A, Croucher NJ, Angiuoli SV et al. Structure and dynamics of the pan-genome of Streptococcus pneumoniae and closely related species. Genome Biol. 2010;11(10):R107. doi:10.1186/gb-2010-11-10-r107.

41. Richards VP, Palmer SR, Pavinski Bitar PD, Qin X, Weinstock GM, Highlander SK et al. Phylogenomics and the dynamic genome evolution of the genus Streptococcus. Genome Biol Evol. 2014;6(4):741-53. doi:10.1093/ gbe/evu048.

42. Cvitkovitch DG. Genetic competence and transformation in oral streptococci. Crit Rev. Oral Biol Med. 2001;12(3):217-43.

43. Atkinson HJ, Morris JH, Ferrin TE, Babbitt PC. Using sequence similarity networks for visualization of relationships across diverse protein superfamilies. PLoS One. 2009;4(2):e4345. doi:10.1371/journal.pone.0004345.

44. Loytynoja A, Goldman N. webPRANK: a phylogenyaware multiple sequence aligner with interactive alignment browser. BMC Bioinformatics. 2010;11:579. doi:10.1186/1471-2105-11-579.

45. Zhang Y. I-TASSER server for protein 3D structure prediction. BMC Bioinformatics. 2008;9:40. doi:10.1186/ 1471-2105-9-40.

46. Bishop CJ, Aanensen DM, Jordan GE, Kilian M, Hanage WP, Spratt BG. Assigning strains to bacterial species via the internet. BMC Biol. 2009;7:3. doi:10.1186/ 1741-7007-7-3.

47. Altschul SF, Gish W, Miller W, Myers EW, Lipman DJ. Basic local alignment search tool. J Mol Biol. 1990;215(3):403-10. doi:10.1016/S0022-2836(05)80360-2.

48. Ruoff KL. Streptococcus anginosus ("Streptococcus milleri"): the unrecognized pathogen. Clin Microbiol Rev. 1988;1(1):102-8.

49. Kilian M, Poulsen K, Blomqvist T, Havarstein LS, Bek-Thomsen M, Tettelin H et al. Evolution of Streptococcus pneumoniae and its close commensal relatives. PLoS One. 2008;3(7):e2683. doi:10.1371/journal.pone.0002683.

\section{Author details}

'Department of Oral Biology, School of Dental Medicine, University at Buffalo, State University of New York, Buffalo, NY, USA. ²Division of Biostatistics and Bioinformatics, Institute of Population Health Sciences, National Health Research Institutes, Miaoli, Taiwan. ${ }^{3}$ Department of Biological Sciences, University at Buffalo, State University of New York, Buffalo, NY, USA. ${ }^{4}$ Department of Oral Biology, School of Stomatology, China Medical

University, Shenyang, People's Republic of China.

Received: 27 June 2017 Accepted: 27 June 2017

Published online: 03 July 2017

\section{Reference}

1. Haase EM, Kou Y, Sabharwal A, Liao YC, Lan T, Lindqvist C, Scannapieco FA. Comparative genomics and evolution of the amylase-binding proteins of oral streptococci. BMC microbiology. 2017 Apr 20;17(1):94. 